2017-04

\title{
Assessing larval connectivity for marine spatial planning in the Adriatic
}

Bray, L

http://hdl.handle.net/10026.1/8447

10.1016/j.marenvres.2017.01.006

Marine Environmental Research

Elsevier BV

All content in PEARL is protected by copyright law. Author manuscripts are made available in accordance with publisher policies. Please cite only the published version using the details provided on the item record or document. In the absence of an open licence (e.g. Creative Commons), permissions for further reuse of content should be sought from the publisher or author. 
1 This is the author's accepted manuscript. The final published version of this work (the version of record) is published by Elsevier in Marine Environmental Research. The accepted manuscript was made available online on the 25 January 2017 at: $\mathrm{http} / / / \mathrm{dx}$.doi.org/10.1016/j.marenvres.2017.01.006. This work is made available online in accordance with the publisher's policies. Please refer to any applicable terms of use of the publisher.

Assessing larval connectivity for marine spatial planning in the Adriatic

Bray, L. ${ }^{1,2}$; Kassis, D ${ }^{1,3} ;$ Hall-Spencer, J.M ${ }^{2,4}$.

1. Hellenic Centre for Marine Research, Institute of Oceanography, Athens, Greece

2. Marine Biology and Ecology Research Centre, University of Plymouth, UK

3. Department of Naval Architecture and Marine Engineering, National Technical University of Athens, Athens, Greece

*Corresponding author: lbray @ hcmr.gr

Abstract

There are plans to start building offshore marine renewable energy devices throughout the Mediterranean and the Adriatic has been identified as a key location for wind farm developments. The development of offshore wind farms in the area would provide hard substrata for the settlement of sessile benthos. Since the seafloor of the Adriatic is predominantly sedimentary this may alter the larval connectivity of benthic populations in the region. Here, we simulated the release of larvae from benthic populations along the coasts of the Adriatic Sea using coupled bio-physical models and investigated the effect of pelagic larval duration on dispersal. Our model simulations show that currents typically carry particles from east to west across the Adriatic, whereas particles released along western coasts tend to remain there with the Puglia coast of Italy acting as a sink for larvae from benthic populations. We identify areas of high connectivity, as well as areas that are much more isolated, and discuss how these results can be used to inform marine spatial planning and the licensing of offshore marine renewable energy developments.

Keywords: marine connectivity; larval dispersion; Adriatic Sea; map equation; Network Theory; marine spatial planning

\subsection{Introduction}

Assessments of larval connectivity are not routinely applied to offshore construction yet structures such as oil rigs and wind farms quickly become colonised by fouling organisms, such as serpulids and barnacles, and over a period of years can develop diverse assemblages of sessile organisms (Bergström et al., 2014). This is because the larvae of most benthic marine organisms are carried on currents. For species with a 24 hour pelagic phase their larvae can travel ca. $1 \mathrm{~km}$, for species that have long pelagic phases the larvae can travel hundreds of $\mathrm{km}$ (Shanks, 2009). This dispersal mechanism is particularly important for sessile macroinvertebrates (Grantham et al., 2003) and the strength of connectivity between populations may help determine their ecological success (Melià et al., 2016; Treml et al., 2012). Offshore structures such as oil rigs and wind farms can act as 'stepping stones' for benthic communities across bio-geographic boundaries (Adams et al., 2014).

Although marine renewable energy developments have not yet begun in the Mediterranean, the Adriatic is being considered for large scale wind farm developments as the region is windy and the sea bed is shallow and well suited to offshore construction (Bray et al., 2016). Here we consider larval connectivity of benthic macroinvertebrates in the region, as this can help predict the types of communities that will colonize (Joschko 
et al., 2008; Wilhelmsson and Malm, 2008), and assess whether they will encourage the spread of nonindigenous species (Bianchi, 2007), both of which are important aspects for the consideration of marine managers.

Few studies have empirically measured the dispersal of marine larvae over large geographic scales (Jones et al., 2009). Indirect methods include the use of genetic markers, geochemical markers, tagging devices, and biophysical dispersal models - all of which have pros and cons (Calò et al., 2013). Bio-physical models are able to track virtual individuals over large temporal and spatial scales (Andrello et al., 2014) although there are major assumptions used with most hydrodynamic-based models, the most significant being the assumed passive nature of the individual larvae particles (Metaxas and Saunders, 2009).

In the Mediterranean, few studies focus on the connectivity and dispersal of marine species (Calò et al., 2013) and this paucity of information is an obstacle for policy makers in the region (Andrello et al., 2015). Those connectivity studies that use virtual particle trajectory methods tend to focus on the establishment and evaluation of marine protected areas (Andrello et al., 2013; Di Franco et al., 2015; Pujolar et al., 2013). Other approaches include the homogenous release of larvae particles throughout the whole Mediterranean (Dubois et al., 2016; Rossi et al., 2014), or the release from specific coastal sites at a regional level (Carlson et al., 2016; Melià et al., 2016; Schiavina et al., 2014; Schunter et al., 2011). Many such studies are tailored to determine connectivity of fish and macroinvertebrate larvae trajectories are seldom modelled in the Mediterranean (Guizien et al., 2014; Padrón and Guizien, 2015; Schiavina et al., 2014).

In the present study, we simulated a release of larvae from benthic populations along the coasts of the Adriatic Sea using coupled bio-physical models and investigated the effect of pelagic larval duration (e.g. simulation duration) on dispersal. We assumed an homogenous larval production and tracked evenly distributed Lagrangian particles for a range of pelagic larval durations $(4,8,16,20$ days) to cover regionally common invertebrate taxa such as barnacles and gastropods (Villamor et al., 2014), rather than utilizing a particular target species (Rossi et al., 2014). We also tracked the likely spread of larvae from benthic populations that originate from the major Adriatic ports, as several studies show an increase in the abundance of non-indigenous species in or around Adriatic ports and marinas (David et al., 2007; Iveša et al., 2015; Pecarevic et al., 2013), and the potential spread of non-indigenous species through corridors of artificial surfaces (Airoldi et al., 2015) is a critical aspect of marine connectivity studies. Essentially, our aim was to identify areas of high vs. low connectivity to inform marine spatial planning and the licensing of offshore marine renewable energy developments.

\subsection{Methods}

Our method was based on the Graph Theory approach used by Rossi et al. (2014) for identifying hydrodynamic provinces throughout the Mediterranean. We modelled the release of Lagrangian particles in evenly distributed grid cells along the Adriatic coastline and then tracked these particles for a range of known pelagic larval durations. Source and destination grid cells were compared to indicate regions of high and low connectivity.

\subsection{Study area}

The Adriatic Sea has a shallow northern section (average depth $40 \mathrm{~m}$ ), a central section (average depth $140 \mathrm{~m}$ ) and a southern section where troughs $>1200 \mathrm{~m}$ deep (Figure 1) channel deep water masses into the Eastern Mediterranean, particularly in late winter (Gačić et al., 2002; Malanotte-Rizzoli et al., 1997). The western coast is generally sandy whereas the eastern side is predominantly rocky (Artegiani et al., 1997) and the hydrography of the basin is influenced by several large rivers (Verri et al., 2014). The circulation is cyclonic overall, with three cyclonic sub-systems in the northern, middle and southern sections and a strong current flowing south along the coast of Italy from spring until autumn (Zavatarelli et al., 1998). 


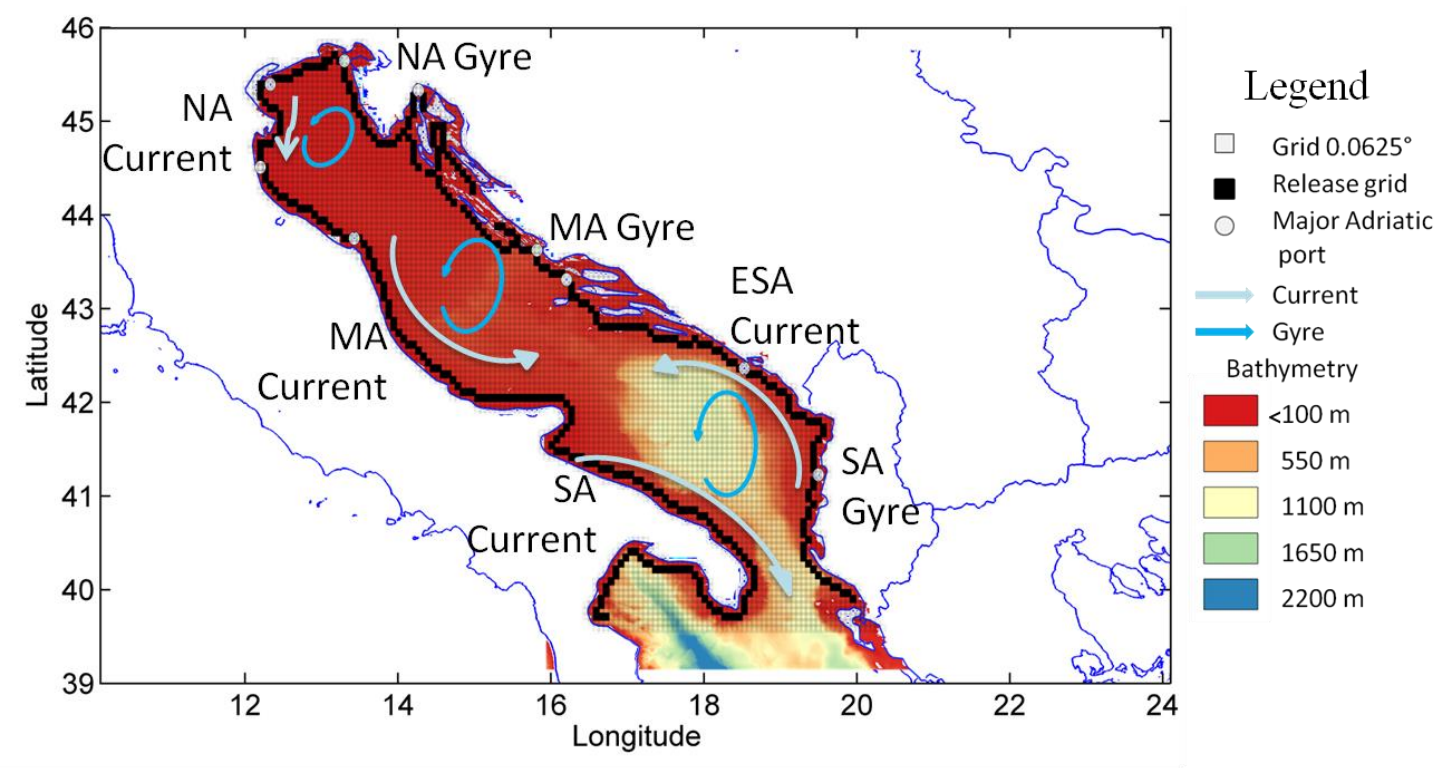

1

Figure 1. Adriatic larval connectivity matrix comprised of a $1 / 16^{\text {th }}$ degree grid into which larval particles were released, showing locations of major ports (clockwise from left: Taranto, Ancona, Ravenna, Venice, Trieste, Rijeka, Sibenik, Split, Tivat, Durres), and major currents $(\mathrm{NA}=$ Northern Adriatic, $\mathrm{MA}=$ Mid-Adriatic, $\mathrm{Sa}=$ South Adriatic, ESA= Eastern South Adriatic. Bathymetry provided by www.emodnet.eu, hydrology adapted from (Artegiani et al., 1997) .

\subsection{Hydrodynamic grid}

Hydrodynamic model output data were obtained from the Mediterranean Monitoring and Forecasting Centre of the Copernicus Marine Environment Monitoring Service (http://marine.copernicus.eu) which has been running since 2000. The model is composed of an Ocean General Circulation Model (Tonani et al., 2013) and a coupled hydrodynamic-wave model with a horizontal grid resolution of $1 / 16^{\circ}(\mathrm{ca} .6-7 \mathrm{~km})$. We subdivided the Adriatic into a $0.0625^{\circ} \times 0.0625^{\circ}$ grid (each grid cell approx. $6.7 \mathrm{~km}^{2}$ ) to match the resolution of the hydrodynamic model giving 383 release grid cells $(\mathrm{S} 1)$.

\subsection{Simulated larval particle transport}

Particles were released from the centre of each of 383 grid cells along the Adriatic coastline and trajectories were followed using the program ICHTHYOP (Lett et al., 2008). No behavioural parameters were assigned to the simulated larval particles thus assuming a passive trajectory. Particle position was calculated every 2 hours, for four pelagic larval durations $(4,8,16$ and, 20 days). We chose consecutive release dates $(n=10)$ throughout June (starting from the 01/06 each year) to coincide with peak benthic macroinvertebrate spawning in the region (Villamor et al., 2014). Particles were released at the same time each day (00:00), and to account for inter-annual variability, the larval dispersal simulations were run for consecutive years covering the period 2011-2015 ( $\mathrm{n}=$ 5). For each larval duration, a cumulative total of 3830 particles were released. A limited tidal range in the Adriatic Sea means atmospheric effects are the main forcing factors in the Adriatic Sea (Bolaños et al., 2014). With respect to this, particle releases were not factored around tidal stages as other larval dispersal models have done in more tide-dominant environments (Narváez et al., 2012).

\subsection{Post-simulation analysis}

Destination grid cells were calculated for each particle using MATLAB6.1, and both descriptive statistics and probability matrices were constructed from an amalgamation of all simulation years and release dates for each larval duration. Additionally a year-on-year analysis of the total distances that particles travelled was done to examine significant differences between years. Due to the non-normal distribution of the data, non-parametric tests (e.g Kruksall-Wallis and Mann-Whitney U Comparison) were used. To visualise the inter-annual differences of the larval trajectories a single simulation track from each year is presented which indicates particle 
position for 4, 8, 16 and 20 day durations. Locations of OWF's in early planning/concept stage as of January 2017 are included for reference

Simulated larvae were considered to have self-replenished if by the end of the simulation potential non-behaviour dispersal trajectories remained in their original release grid. Probabilities of particle arrival were mapped for each grid cell and particle transport distances were calculated. To provide information on larval transport from industrialized regions (Figure 1), release grids located closest to the ten major Adriatic ports were selected and the particles released from these sites were presented separately.

We used Infomap to define network structure (Rosvall and Bergstrom, 2008) and it allowed us to examine cells within our grid of across the Adriatic Sea and determine where larval transport can be expected to flow quickly and easily between them, for details see Rossi et al., (2014). In addition to community detection, Infomap also provides information on the importance of individual nodes via the use of its pageRank algorithm. PageRank (commonly used for ranking web pages) provides a nonlocal measure of centrality by defining the expected density of random walkers on a node at stationarity, within a weighted, directional, network (Lambiotte and Rosvall, 2012). PageRank for each cell is presented as a probability distribution with a numerical value between 0 and 1, i.e. a cell with a pageRank of 0.5 means that a random walker within the network would have a $50 \%$ chance of arriving at the given cell. Identifying the highest and lowest ranked nodes for each pelagic larval duration illustrates the most and least important grid cells within each network.

\subsection{Results}

As expected, simulated increases in the duration of particle transport resulted in an increase in the distance travelled. Likewise, as dispersal duration increased, self-replenishment decreased. Overall levels of selfreplenishment were very low, but were an order of magnitude higher at release grids close to Adriatic Ports (Table 1), likely due to the typical positioning of ports in enclosed bays. Dispersal distances increased from around $11 \mathrm{~km}$ for 4 day simulations, to $30 \mathrm{~km}$ for larvae that could survive for 20 days in the plankton and the greatest distance travelled by a particle during the 20 day simulation was $334 \mathrm{~km}$ (Table 1). The large Standard Deviations around each mean show that some particles remained close to the simulated release sites, whereas others travel far; this variability increased with dispersal duration.

Table 1. Descriptive statistics for particle trajectories (Avg. = Average, $\mathrm{SD}=$ Standard deviation, $\mathrm{SR}=$ self replenishment).

\begin{tabular}{|c|cccc|}
\cline { 2 - 5 } \multicolumn{1}{c|}{} & $\mathbf{4}$ days & $\mathbf{8}$ days & 16 days & 20 days \\
\hline Furthest distance $(\mathbf{k m})$ & 88.7 & 205.5 & 308.3 & 334.7 \\
Avg. distance $(\mathbf{k m}) \pm$ SD & $11.0 \pm 11.0$ & $16.8 \pm 17.3$ & $25.7 \pm 28.1$ & $29.5 \pm 34.0$ \\
Avg. Distance from ports (km) \pm SD & $7.6 \pm 6.3$ & $12.2 \pm 12.4$ & $20.3 \pm 12.7$ & $24.4 \pm 30.9$ \\
Avg. SR $(\%) \pm$ SD & $0.01 \pm 0.1$ & $0.01 \pm 0.00$ & $0.01 \pm 0.00$ & $0.01 \pm 0.00$ \\
Avg. SR at port sites $(\%) \pm$ SD & $0.11 \pm 0.12$ & $0.07 \pm 0.06$ & $0.04 \pm 0.07$ & $0.04 \pm 0.07$ \\
\hline
\end{tabular}

Regarding inter-annual differences of the distances that the simulated particles travelled, the non-parametric (due to extreme outliers of the data) statistical test Kruskal-Wallis test for equal medians was used to compare differences between years. All the pelagic larval duration simulations expressed significant differences between years (For PLD4 H(2) = 856.82, $p=0.00$; PLD8, H(2) = 661, $p=0.00$; PLD16, H(2) = 480.91, $p=0.00$; and PLD20, H(2) $=387, p=0.00$ (2 s.f.). Post hoc Mann-Whitney tests for yearly differences within each PLD showed most years are significantly different, with only 6 years not showing any significant differences (Table 2). 
Table 2. Matrix of Mann-Whitney test value (U), and probability ( $p$ ), for each comparison of year-on-year particle distance for each dispersal duration. Highlighted in bold are yearly comparisons which show NO statistical differences. Values for Mann-Whitney test value (U) are shown to 3 s.f, and probability values $(p)$, are shown to 2 s.f.

\begin{tabular}{|c|c|c|c|c|c|}
\hline & & 2012 & 2013 & 2014 & 2015 \\
\hline & 2011 & $\begin{array}{c}\mathrm{U}=7020000 \\
\quad p=0.04\end{array}$ & $\begin{array}{c}\mathrm{U}=5500000 \\
p=0.00\end{array}$ & $\begin{array}{c}\mathrm{U}=6260000 \\
p=0.00\end{array}$ & $\begin{array}{c}\mathrm{U}=5320000, \\
p=0.00\end{array}$ \\
\hline & 2012 & & $\begin{array}{c}\mathrm{U}=5300000 \\
p=0.00\end{array}$ & $\begin{array}{c}\mathrm{U}=6030000 \\
p=0.00\end{array}$ & $\begin{array}{c}\mathrm{U}=5100000 \\
p=0.00\end{array}$ \\
\hline & 2013 & & & $\begin{array}{c}\mathrm{U}=6600000 \\
p=0.00\end{array}$ & $\begin{array}{c}\mathrm{U}=7190000 \\
p=1.00\end{array}$ \\
\hline & 2014 & & & & $\begin{array}{c}\mathrm{U}=6450000, \\
p=0.00\end{array}$ \\
\hline \multirow{4}{*}{$\stackrel{\infty}{\hat{a}}$} & 2011 & $\begin{array}{c}\mathrm{U}=7220000 \\
p=0.93\end{array}$ & $\begin{array}{c}\mathrm{U}=5760000 \\
p=0.00\end{array}$ & $\begin{array}{c}\mathrm{U}=6400000 \\
p=0.00\end{array}$ & $\begin{array}{c}\mathrm{U}=5260000 \\
p=0.00\end{array}$ \\
\hline & 2012 & & $\begin{array}{c}\mathrm{U}=5870000 \\
p=0.00\end{array}$ & $\begin{array}{c}\mathrm{U}=6500000 \\
p=0.00\end{array}$ & $\begin{array}{c}\mathrm{U}=5380000 \\
p=0.00\end{array}$ \\
\hline & 2013 & & & $\begin{array}{c}\mathrm{U}=6690000 \\
p=0.00\end{array}$ & $\begin{array}{c}\mathrm{U}=6860000 \\
p=0.00\end{array}$ \\
\hline & 2014 & & & & $\begin{array}{c}\mathrm{U}=6230000 \\
p=0.00\end{array}$ \\
\hline \multirow{4}{*}{$\frac{0}{a}$} & 2011 & $\begin{array}{c}\mathrm{U}=7070000 \\
p=0.18\end{array}$ & $\begin{array}{c}\mathrm{U}=6820000 \\
\quad p=0.00\end{array}$ & $\begin{array}{c}\mathrm{U}=6840000 \\
p=0.00\end{array}$ & $\begin{array}{c}\mathrm{U}=5560000 \\
p=0.00\end{array}$ \\
\hline & 2012 & & $\begin{array}{c}\mathrm{U}=6630000 \\
p=0.00\end{array}$ & $\begin{array}{c}\mathrm{U}=6640000 \\
p=0.00\end{array}$ & $\begin{array}{c}\mathrm{U}=5420000 \\
p=0.00\end{array}$ \\
\hline & 2013 & & & $\begin{array}{c}\mathrm{U}=7260000 \\
p=1.00\end{array}$ & $\begin{array}{c}\mathrm{U}=6060000 \\
p=0.00\end{array}$ \\
\hline & 2014 & & & & $\begin{array}{c}\mathrm{U}=5990000 \\
p=0.00\end{array}$ \\
\hline \multirow{4}{*}{ 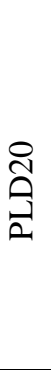 } & 2011 & $\begin{array}{c}\mathrm{U}=7080000 \\
p=0.26\end{array}$ & $\begin{array}{c}\mathrm{U}=6940000 \\
p=0.00\end{array}$ & $\begin{array}{c}\mathrm{U}=7000000 \\
p=0.02\end{array}$ & $\begin{array}{c}\mathrm{U}=5770000 \\
p=0.00\end{array}$ \\
\hline & 2012 & & $\begin{array}{c}\mathrm{U}=6750000 \\
p=0.00\end{array}$ & $\begin{array}{c}\mathrm{U}=6800000 \\
\boldsymbol{p}=\mathbf{0 . 0 0}\end{array}$ & $\begin{array}{c}\mathrm{U}=5620000 \\
p=0.00\end{array}$ \\
\hline & 2013 & & & $\begin{array}{c}\mathrm{U}=7240000 \\
p=1.00\end{array}$ & $\begin{array}{c}\mathrm{U}=6100000 \\
p=0.00\end{array}$ \\
\hline & 2014 & & & & $\begin{array}{c}\mathrm{U}=6030000 \\
p=0.00\end{array}$ \\
\hline
\end{tabular}

\subsection{Particle transport}

In agreement with the statistical analysis of the year-on-year differences between distance travelled of individual particles, the spatial depiction of the particle trajectories indicates high inter-annual variabilities (Figure 2). Larval sink locations (locations where particle tracks terminate) are not consistent, and although no clear interannual trends are apparent, an increased inter-connection between the east and west coasts after 2013 is noticeable. The model simulates particle transport from the central-eastern coastline to the west coast within the $41^{\circ}-44^{\circ}$ latitudes for the years 2013,2014 and 2015. 

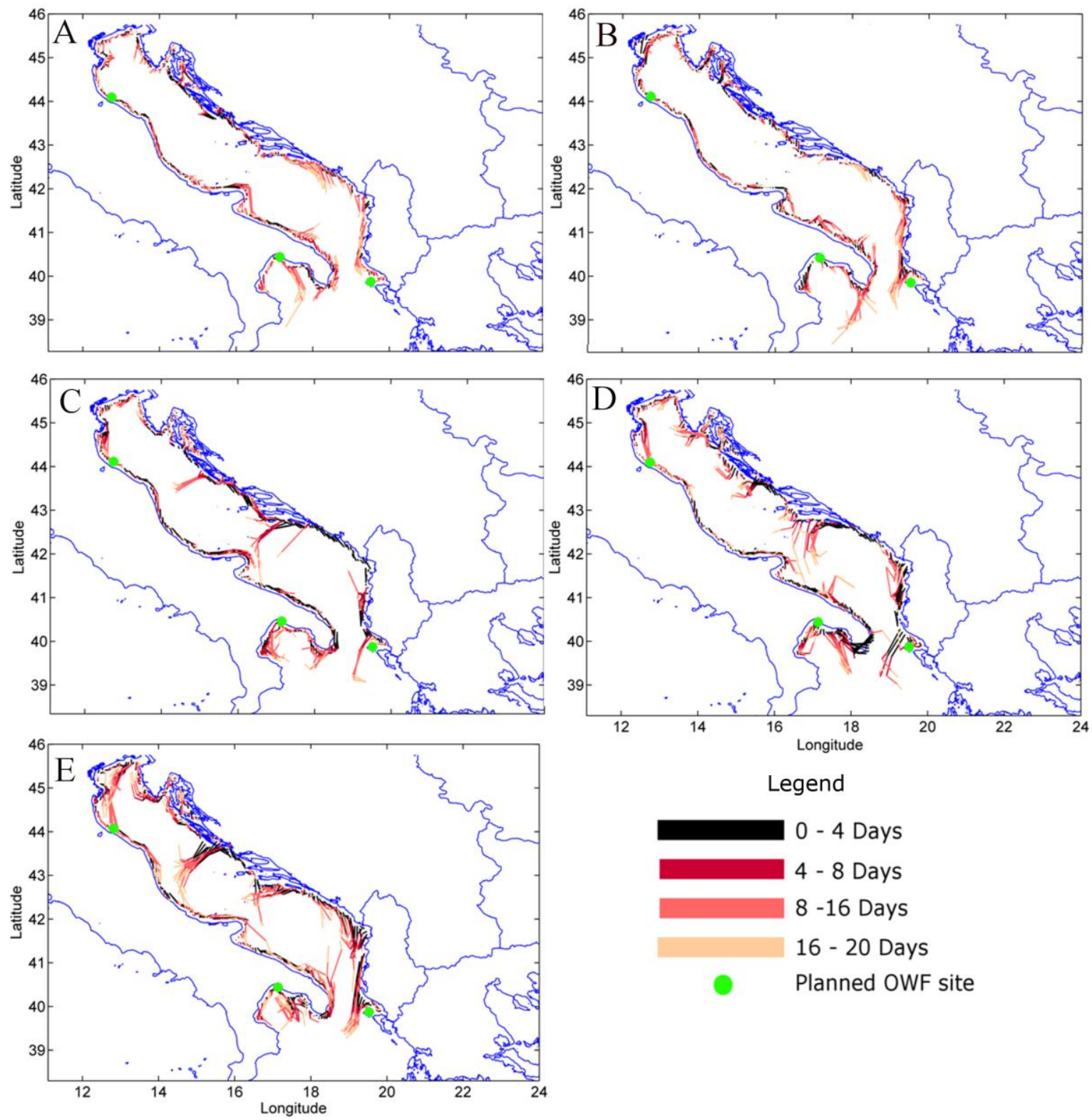

Legend

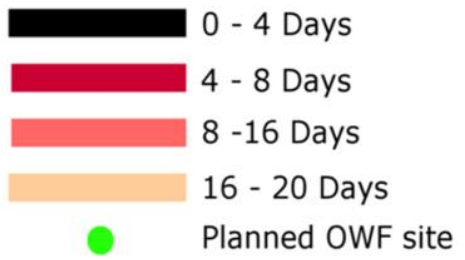

Figure 2. A single track simulation to indicate source/sink information is presented with particle position taken from simulations of the $1^{\text {st }}$ of June for each year. Panel A indicates the trajectory for the $1^{\text {st }}$ of June 2011, B $=2012, C=2013, D=2014$, and $E=2015$. Positions shown for each time interval (0-4 day, 4-8 days, 8-16 days, and 16- 20 days), and locations of offshore wind farms currently in the early planning/concept stage in the region are also depicted (http://www.4coffshore.com).

After a simulation duration of four days, regions of grid cells with high concentrations of larval trajectory destination points include the region South of the river Durres delta, the port of Rijeka, the Kvarner Gulf (Croatia), the Gulf of Trieste, Gulf of Venice, and many locations along the Italian Adriatic Coast. Regions with grid cells of lower count densities include the Po river delta, and the offshore region of the Dalmatia coast. Similar results were found for 8,16 and 20 day durations with areas of low densities of larval trajectory destination points being mostly restricted to offshore regions such as the Bay of Kotor, the Southern Region of Gulf of Trieste, and the Po river delta (Figure 3). A more detailed depiction in the form of a probability matrices is provided in the supplementary files (S2, S3, S4 and S5). 

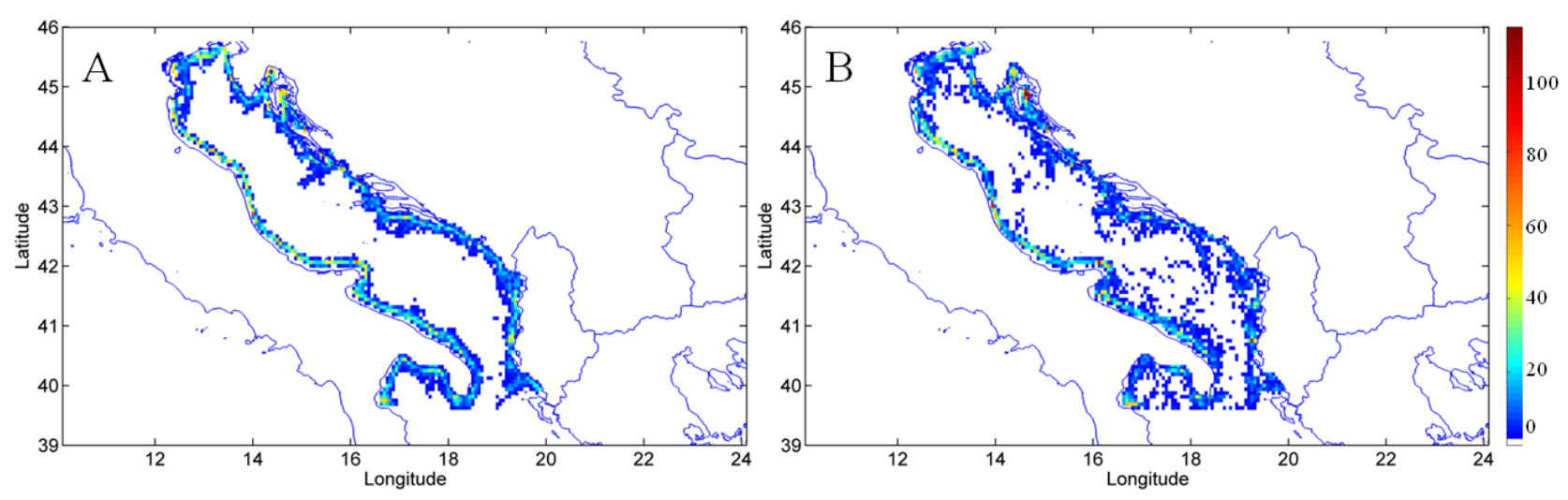

Figure 3 Grid count densities of destination points of larval trajectories for A) four and B) 20 day larval durations. All PLD simulations produced similar patterns, albeit increasing dispersion with increasing larval duration so for convenience only the minimum and maximum larval durations are displayed. Counts measured in absolute terms.

A high concentration of port destination cells was also located close to Split, the largest passenger port in the region, for all durations. For simulation durations of 8, 16 and 20 days, large sections of Albanian coast indicated high concentrations of larval trajectory destination points having being released from areas in close vicinity of ports (Figure 4).
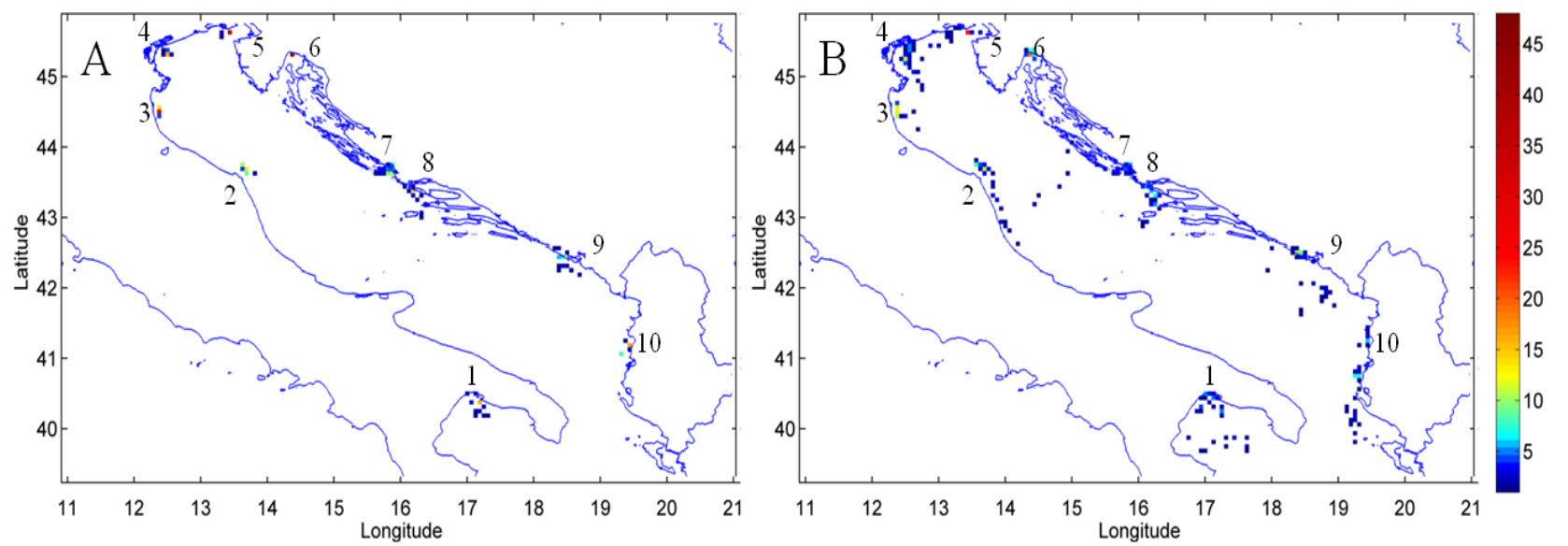

Figure 4. Grid count densities of destination points of larval trajectories for each grid cell closest to each major Adriatic port for A) four and B) 20 day larval dispersal. Numbers indicate port locations: $1=$ Taranto, $2=$ Ancona, $3=$ Ravenna, 4= Venice, 5= Trieste, 6= Rijeka, $7=$ Sibenik, $8=$ Split, $9=$ Tivat, $10=$ Durres. Count densities are not defined by their release points. All PLD simulations produced similar patterns, albeit increasing dispersion with increasing larval duration so for convenience only the minimum and maximum larval durations are displayed Counts measured in absolute terms.

After 4 days, the grid cells within the network with relatively high self-replenishment included the Manfredonia Gulf, the Kvarner Gulf, the Adriatic coast of Italy, and south of the Po river delta. Regions of relatively lower cells of self-replenishment include the Po delta, the Gulf of Trieste, and the northern coast of Croatia. For durations of 8,16 and 20 days the only relatively high self-replenishment regions were the Manfredonia Gulf, and the Kvarner Gulf, whilst the regions with very little self-replenishment include the Po delta, South of Gulf of Trieste, and most of the Kvarner Gulf (Figure 5). 

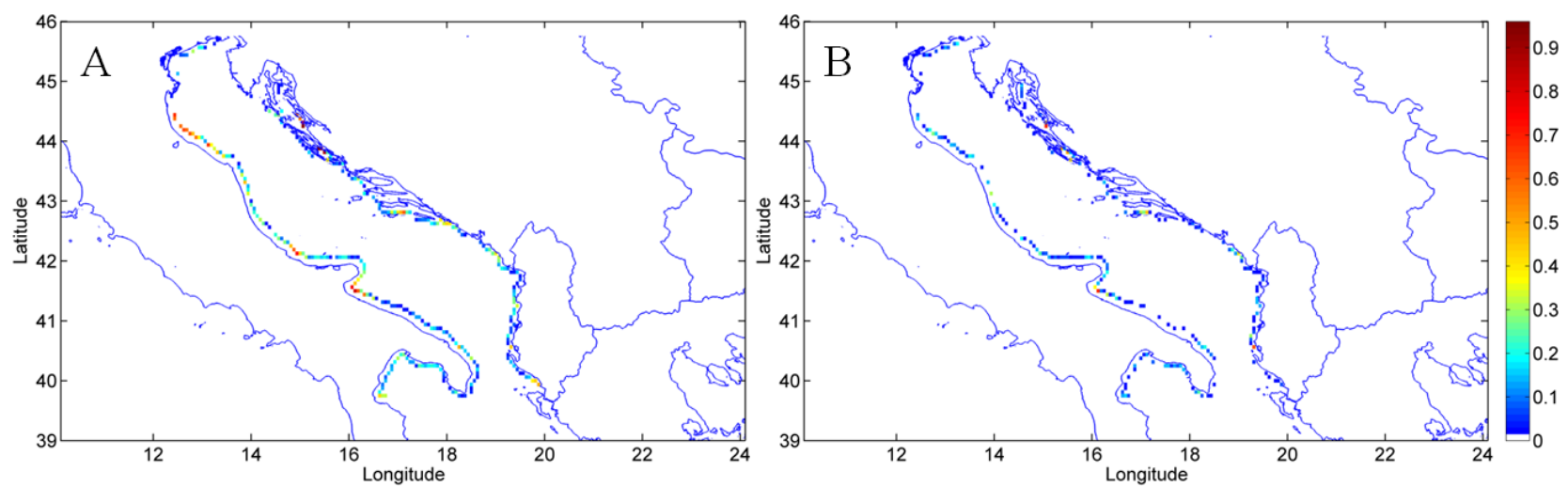

Figure 5. Percentage of self-replenishment for each release grid cell for A) four and B) 20 day larval durations. All PLD simulations produced similar patterns, albeit increasing dispersion with increasing larval duration so for convenience only the minimum, and maximum, larval durations are displayed. Increasing the larval duration means the self-replenishment of most release grids along the Eastern coast of the Adriatic approaches $0 \%$.

$6 \quad 3.2$ Clusters and node centrality within network

An increase of simulation duration resulted in fewer numbers of identified communities with the mapequation algorithm. Infomap clustering (Figure 6) indicated that the four day larval duration, a transport network with 2022 nodes and 4883 links, was clustered into 76 modules with 110 inter-module links. The eight day larval duration, a network of 2362 nodes with 6462 links, was clustered into six modules with two inter-module links. Whilst both 16 ( 2650 nodes with 7484 links) and the 20 day duration (2764 nodes with 7812 links) were clustered into four modules with one inter-module link.
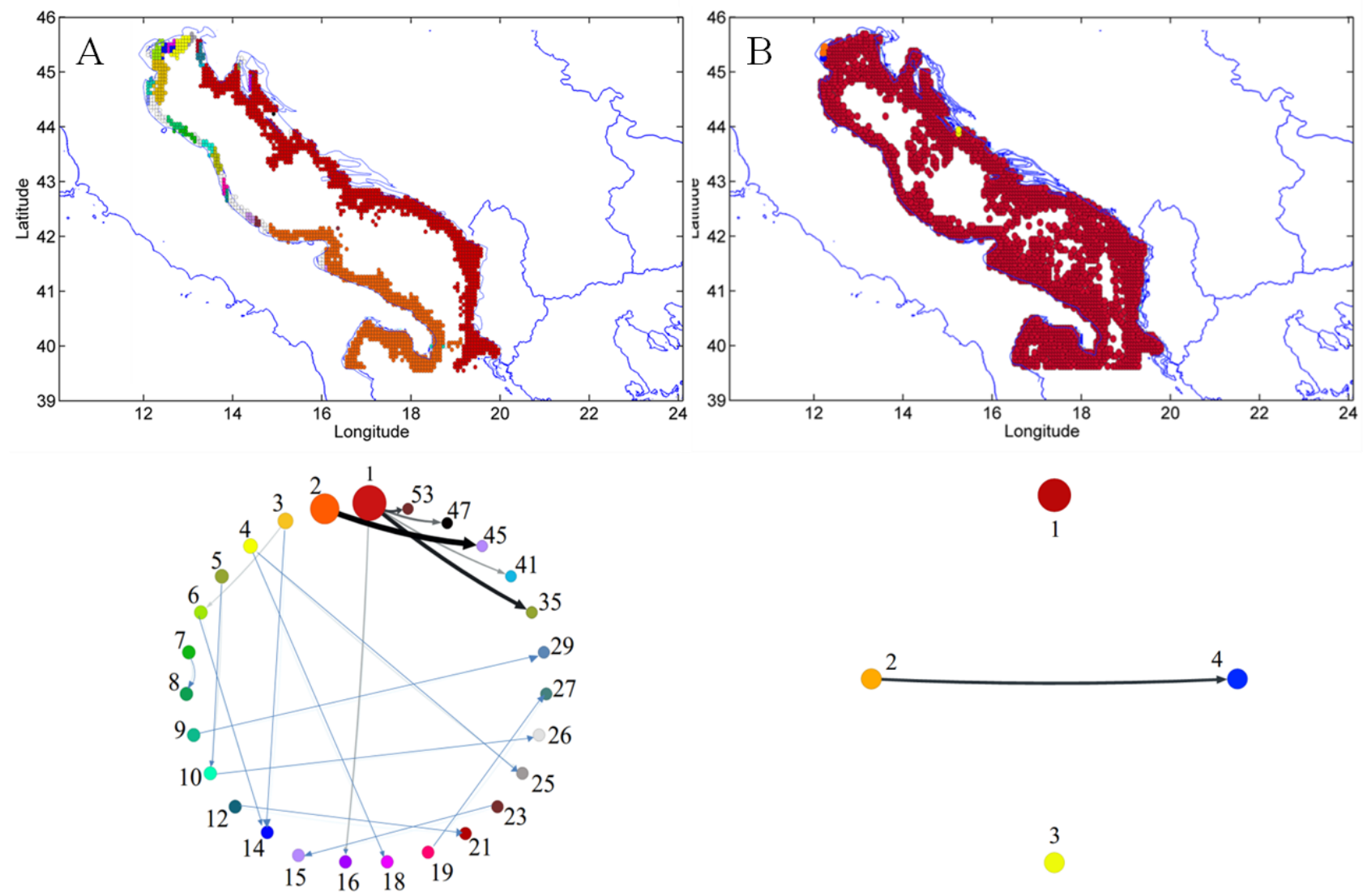

Figure 6. Community outputs from mapequation algorithm displayed spatially A) four and B) 20 day larval durations. Relative strength of 

convenience only the minimum and maximum larval durations are displayed.

3 Mapping the PageRank for each grid cell indicated that for all PLD's the Adriatic coast of Italy contained some 4 of the highest ranked grid cells along with two locations within the Kvarner Gulf (Croatia), thus indicating these 5 regions contained some of the most connected cells within the network. Regions with consistently lower ranked 6 grid cells and thus less connected were the offshore basin regions (all durations), the Po river delta (four day), and the Montenegro and Albanian coast (eight, 16, and 20 day durations) (Figure 7)
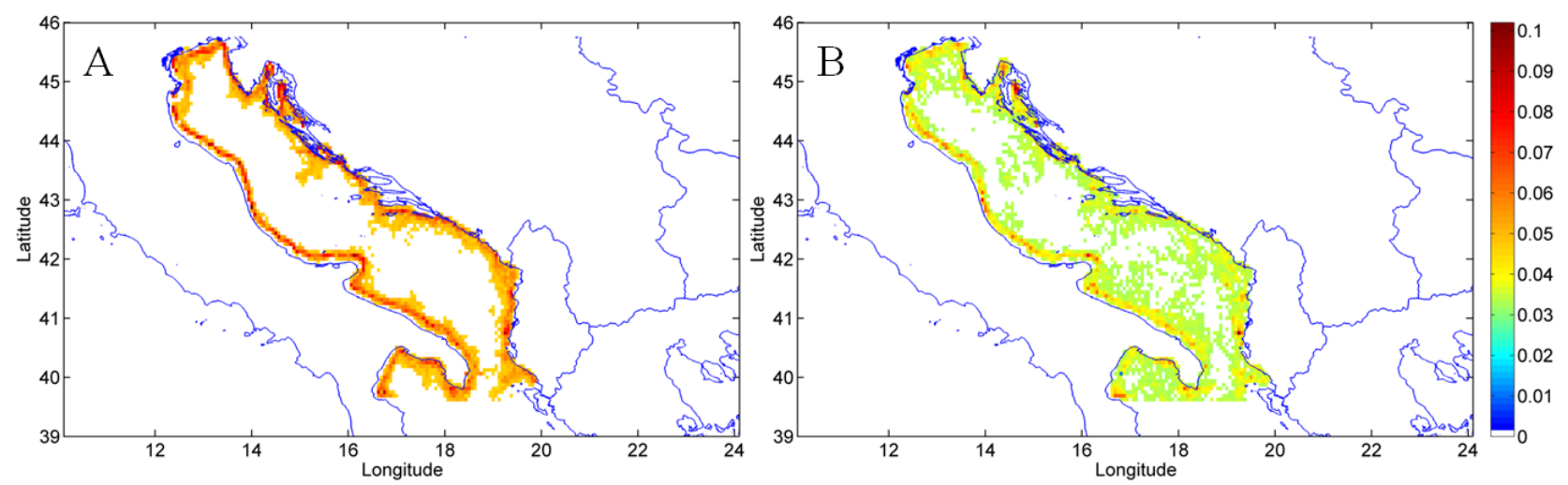

Figure 7.Spatial display of PageRank for each grid cell included within the network for A) four and B) 20 day larval durations. No distinction made between grid cells given a PageRank value of zero and grid cells not assigned a Pagerank value. The scale indicates the probability distribution as numeric values ranging between 0 and 0.1 . All PLD simulations produced similar patterns, albeit increasing dispersion with increasing larval duration, so for convenience only the minimum and maximum larval durations are displayed.

\subsection{Discussion}

The Adriatic region is a distinct marine sub-region assigned as a priority region for marine spatial planning (Bastari et al., 2016). High activity use often creates conflicts between economic development of the region, habitat protection, and preservation of biodiversity. The region already has a great deal of offshore activities (Manoukian et al., 2010) and there is scope for rapid development of offshore wind farms, particularly in the Northern Adriatic (Bray et al., 2016). Here we explore how these developments will impact the marine benthic environment. The Adriatic Sea is managed nationally with several of the six coastal states sharing the use of territorial waters; the co-ordination of marine management in this region is often fragmented. Due to the interconnected cross-boundary nature of marine systems, the approach presented here may prove useful in fostering basin-scale management of the biological impacts of offshore construction in the Adriatic Sea.

\subsection{Methodological approach}

Three dimensional particle tracking models is useful for quantifying the dispersal of benthic invertebrate larvae (Metaxas and Saunders, 2009) and Graph Theory is an effective tool for exploring patterns of spatial connectivity (Treml et al., 2007). This approach has been widely used for the identification and evaluation of marine protected areas; however this is the first time it has been used as an aid for planning offshore construction. Nevertheless, there are several limitation associated with the approach. Real-world realization of the findings presented here requires additional information such as individual larval behaviour (Zhang et al., 2016), predator-prey interactions, environmental cues, and suitable substratum availability for settlement (Chan and Walker, 1998). The homogenous release of passive particles along the Adriatic coastline does not accurately reflect nature but it does provide an insight into larval dispersal over large scales at an ecosystem level, and is a useful starting point for marine spatial planners.

\subsection{Particle transport}

The distance larval particles were transported was shorter than other works which assessed dispersal distances in the region (Melià et al., 2016) as they used longer pelagic larval durations. Some of the most prolific biofoulers 
of the region (balanoid barnacles, serpulid worms, and ascidians) have short pelagic larval durations ranging from several hours to up to three weeks (Anil et al., 1995; Chan and Walker, 1998; Jacobs et al., 2006). The limited dispersal potential reflected within the 4, 8, 16 and 20 day simulations in comparison to the typical pelagic fish connectivity modelling of the Mediterranean (approximately 30 days) highlights the need for taxonspecific connectivity analyses.

Regarding the spatial dispersal of larval particles, there are several persistent larval sinks along the southern Italian shore, corroborating previous findings in the region (Dubois et al., 2016). The shelf area along the Western coast of Italy, consistently had high larval densities in our simulations due to the hydrographic influence of the River Po (Orlic et al., 1992). During winter, the river output is confined to the Northern basin but during the spring/summer spawning season the Mid Western Adriatic current, and the South Western Adriatic currents, transverse the entire Western coastline of Italy (Artegiani et al., 1997) (Figure 1). Offshore structures constructed along the southern Italian shores are likely to be much more exposed to larval settlement than other locations. Similarly, other regions that indicate relatively high self-replenishment and larval densities are found within the Kravner Gulf. The convoluted coastline of the Croatian archipelago clearly plays a large role in transportation of larval particles within the region.

Dispersal of simulated larvae that originate from the major ports of the Adriatic, congregate in high concentrations throughout the Northern basin, largely due to the close proximity of the port of Ravenna, the port of Venice, and the port of Trieste (Figure 1). Multiple studies have shown higher abundances of alien species at several Adriatic ports (David et al., 2007; Iveša et al., 2015); likely due to direct transportation from fouling/ballast water or indirectly via the colonization of artificial substratum. The invasive barnacle Amphibalanus improvises has been recorded at the Rovinj port in Croatia (Pecarevic et al., 2013). Despite it's fairly limited pelagic larval duration of 5 - 20 days (Anil et al., 1995), its high reproductive capacity and rapid establishment on both natural and artificial substrates has caused it to be classified as one of the worst invasive species in Europe (Vilà et al., 2009). The high numbers of alien macroinvertebrates in the region (Zenetos et al., 2012), and the disproportionate advantage they often have in colonizing artificial substrata, means that offshore wind farms may create corridors for alien species invasions (Airoldi et al., 2015). Information regarding the likely destination of larval particles originating from ports and marinas in the Adriatic may assist marine spatial planners looking to reduce the spread of invasive non-indigenous species in the region; however in areas like the Northern basin, high densities of existing ports and infrastructures may mean the colonization of alien species on offshore structures is unavoidable.

\subsection{Node centrality}

Our principal result was the production of benthic invertebrate 'connectivity' map in the Adriatic. Grid cell centrality i.e. PageRank, is a good way of estimating how connected this cell is with the rest of the grid cells within the network. This measure can be important when spatially planning the position of offshore artificial structures. The potential for offshore structures to act as stepping stones by providing a suitable habitat for colonisation in areas outside of the typical range extension of a species is already documented (Adams et al., 2014), and can have both local and regional impacts on the maintenance of local biodiversity within marine ecosystems (Dafforn et al., 2015). On average, grid cells had low connectivity for all PLDs, particularly in offshore regions and the Po river delta; there were however, several regions of high importance within the network which included the Port of Rijeka, Italian Adriatic coast, and South of the river Durres. This information presented here will be important when deciding if offshore activities should be designed to increase, or decrease, benthic community connectivity. Of the connected grid cells the vast majority ( $>90 \%$ of cells with pelagic duration more than four days) involved in the coastline-release network were part of one cluster, indicating that although connectivity of grid cells is relatively low, there is potential for interconnection throughout the whole Adriatic.

Connectedness of regions, particularly regions outside of marine protected areas, is an often-ignored aspect of marine spatial planning, but with the further development of offshore activities in the area and the likely impacts 
this expansion will have on marine biodiversity it should be an important consideration for regional marine spatial planners. The approach presented here is a pragmatic tool for identifying connectivity systems of benthic communities within a semi-closed system which can be expanded with in-situ data regarding the placement of offshore structures and habitat ranges of key benthic species. Identifying regions of relatively higher connectivity within the region i.e. the Italian Adriatic coast, south of the river Durres and port of Rijeka, is a useful starting point for providing information towards an intergraded management approach of the Adriatic Sea.

\subsection{Acknowledgements}

This work was supported by the 'Towards Coast to Coast NETworks of marine protected areas (from the shore to the high and deep sea), coupled with sea-based wind energy potential' project (COCONET) from European Community's Seventh Framework Programme (FP7/2007-2013) under Grant Agreement No.287844 and the EMODNET MedSea checkpoint project (www.emodnet.eu/med-sea). The freely available hydrodynamic dataset was generated by MyOcean (http://marine.copernicus.eu). The larval release simulation was provided as a freely available Java tool from ICHTHYOP (http://www.ichthyop.org/). Flash applet for understanding community structure in networks is freely available online at http://www.mapequation.org/. The authors would also like to thank Phillipe Verley for his technical assistance regarding the implementation of the ICHTHYOP java tool.

\subsection{References}

Adams, T.P., Miller, R.G., Aleynik, D., Burrows, M.T., 2014. Offshore marine renewable energy devices as stepping stones across biogeographical boundaries. J. Appl. Ecol. 51, 330-338. doi:10.1111/13652664.12207

Airoldi, L., Turon, X., Perkol-Finkel, S., Rius, M., 2015. Corridors for aliens but not for natives: effects of marine urban sprawl at a regional scale. Divers. Distrib. 21, 755-768. doi:10.1111/ddi.12301

Andrello, M., Jacobi, M.N., Manel, S., Thuiller, W., Mouillot, D., 2014. Extending networks of protected areas to optimize connectivity and population growth rate. Ecography n/a-n/a. doi:10.1111/ecog.00975

Andrello, M., Mouillot, D., Somot, S., Thuiller, W., Manel, S., 2015. Additive effects of climate change on connectivity between marine protected areas and larval supply to fished areas. Divers. Distrib. 21, 139-150. doi:10.1111/ddi.12250

Anil, A., Chiba, K., Okamoto, K., Kurokura, H., 1995. Influence of temperature and salinity on larval development of Balanus amphitrite: implications in fouling ecology. Mar. Ecol. Prog. Ser. 118, 159166. doi:10.3354/meps118159

Artegiani, A., Paschini, E., Russo, A., Bregant, D., Raicich, F., Pinardi, N., 1997. The Adriatic Sea General Circulation. Part I: Air-Sea Interactions and Water Mass Structure. J. Phys. Oceanogr. 27, 14921514. doi:10.1175/1520-0485(1997)027<1492:TASGCP>2.0.CO;2

Bastari, A., Micheli, F., Ferretti, F., Pusceddu, A., Cerrano, C., 2016. Large marine protected areas (LMPAs) in the Mediterranean Sea: The opportunity of the Adriatic Sea. Mar. Policy 68, 165-177. doi:10.1016/j.marpol.2016.03.010

Bergström, L., Kautsky, L., Malm, T., Rosenberg, R., Wahlberg, M., Capetillo, N.Å., Wilhelmsson, D., 2014. Effects of offshore wind farms on marine wildlife - a generalized impact assessment. Environ. Res. Lett. 9, 34012. doi:10.1088/1748-9326/9/3/034012

Bianchi, C.N., 2007. Biodiversity issues for the forthcoming tropical Mediterranean Sea, in: Relini, G., Ryland, J. (Eds.), Biodiversity in Enclosed Seas and Artificial Marine Habitats, Developments in Hydrobiology. Springer Netherlands, pp. 7-21.

Bolaños, R., Tornfeldt Sørensen, J.V., Benetazzo, A., Carniel, S., Sclavo, M., 2014. Modelling ocean currents in the northern Adriatic Sea. Cont. Shelf Res., Oceanography at coastal scales 87, 54-72. doi:10.1016/j.csr.2014.03.009

Bray, L., Reizopoulou, S., Voukouvalas, E., Soukissian, T., Alomar, C., Vázquez-Luis, M., Deudero, S., Attrill, M.J., Hall-Spencer, J.M., 2016. Expected Effects of Offshore Wind Farms on Mediterranean Marine Life. J. Mar. Sci. Eng. 4, 18.

Calò, A., Félix-Hackradt, F.C., Garcia, J., Hackradt, C.W., Rocklin, D., Otón, J.T., Charton, J.A.G., 2013. A review of methods to assess connectivity and dispersal between fish populations in the Mediterranean Sea. Adv. Oceanogr. Limnol. 4, 150-175. doi:10.1080/19475721.2013.840680 
Carlson, D.F., Griffa, A., Zambianchi, E., Suaria, G., Corgnati, L., Magaldi, M.G., Poulain, P.-M., Russo, A., Bellomo, L., Mantovani, C., Celentano, P., Molcard, A., Borghini, M., 2016. Observed and modeled surface Lagrangian transport between coastal regions in the Adriatic Sea with implications for marine protected areas. Cont. Shelf Res. 118, 23-48. doi:10.1016/j.csr.2016.02.012

Chan, A.L.C., Walker, G., 1998. The settlement of Pomatoceros lamarckii larvae (Polychaeta: Sabellida : Serpulidae): A laboratory study. Biofouling 12, 71-80. doi:10.1080/08927019809378347

Dafforn, K.A., Glasby, T.M., Airoldi, L., Rivero, N.K., Mayer-Pinto, M., Johnston, E.L., 2015. Marine urbanization: an ecological framework for designing multifunctional artificial structures. Front. Ecol. Environ. 13, 82-90. doi:10.1890/140050

David, M., Gollasch, S., Cabrini, M., Perkovič, M., Bošnjak, D., Virgilio, D., 2007. Results from the first ballast water sampling study in the Mediterranean Sea - the Port of Koper study. Mar. Pollut. Bull. 54, 53-65. doi:10.1016/j.marpolbul.2006.08.041

Dubois, M., Rossi, V., Ser-Giacomi, E., Arnaud-Haond, S., López, C., Hernández-García, E., 2016. Linking basin-scale connectivity, oceanography and population dynamics for the conservation and management of marine ecosystems. Glob. Ecol. Biogeogr. n/a-n/a. doi:10.1111/geb.12431

Gačić, M., Civitarese, G., Miserocchi, S., Cardin, V., Crise, A., Mauri, E., 2002. The open-ocean convection in the Southern Adriatic: a controlling mechanism of the spring phytoplankton bloom. Cont. Shelf Res. 22, 1897-1908. doi:10.1016/S0278-4343(02)00050-X

Grantham, B.A., Eckert, G.L., Shanks, A.L., 2003. Dispersal Potential of Marine Invertebrates in Diverse Habitats. Ecol. Appl. 13, 108-116. doi:10.1890/1051-0761(2003)013[0108:DPOMII]2.0.CO;2

Guizien, K., Belharet, M., Moritz, C., Guarini, J.M., 2014. Vulnerability of marine benthic metapopulations: implications of spatially structured connectivity for conservation practice in the Gulf of Lions (NW Mediterranean Sea). Divers. Distrib. 20, 1392-1402. doi:10.1111/ddi.12254

Iveša, L., Djakovac, T., Devescovi, M., 2015. Spreading patterns of the invasive Caulerpa cylindracea Sonder along the west Istrian Coast (northern Adriatic Sea, Croatia). Mar. Environ. Res. 107, 1-7. doi:10.1016/j.marenvres.2015.03.008

Jacobs, M.W., Degnan, S.M., Woods, R., Williams, E., Roper, K.E., Green, K., Degnan, B.M., 2006. The effect of larval age on morphology and gene expression during ascidian metamorphosis. Integr. Comp. Biol. 46, 760-776. doi:10.1093/icb/icl015

Jones, G.P., Almany, G.R., Russ, G.R., Sale, P.F., Steneck, R.S., Oppen, M.J.H. van, Willis, B.L., 2009. Larval retention and connectivity among populations of corals and reef fishes: history, advances and challenges. Coral Reefs 28, 307-325. doi:10.1007/s00338-009-0469-9

Joschko, T.J., Buck, B.H., Gutow, L., Schröder, A., 2008. Colonization of an artificial hard substrate by Mytilus edulis in the German Bight. Mar. Biol. Res. 4, 350-360. doi:10.1080/17451000801947043

Lett, C., Verley, P., Mullon, C., Parada, C., Brochier, T., Penven, P., Blanke, B., 2008. A Lagrangian tool for modelling ichthyoplankton dynamics. Environ. Model. Softw. 23, 1210-1214. doi:10.1016/j.envsoft.2008.02.005

Malanotte-Rizzoli, P., Manca, B.B., D’Alcalà, M.R., Theocharis, A., Bergamasco, A., Bregant, D., Budillon, G., Civitarese, G., Georgopoulos, D., Michelato, A., Sansone, E., Scarazzato, P., Souvermezoglou, E., 1997. A synthesis of the Ionian Sea hydrography, circulation and water mass pathways during POEM-Phase I. Prog. Oceanogr. 39, 153-204. doi:10.1016/S0079-6611(97)00013-X

Manoukian, S., Spagnolo, A., Scarcella, G., Punzo, E., Angelini, R., Fabi, G., 2010. Effects of two offshore gas platforms on soft-bottom benthic communities (northwestern Adriatic Sea, Italy). Mar. Environ. Res. 70, 402-410. doi:10.1016/j.marenvres.2010.08.004

Melià, P., Schiavina, M., Rossetto, M., Gatto, M., Fraschetti, S., Casagrandi, R., 2016. Looking for hotspots of marine metacommunity connectivity: a methodological framework. Sci. Rep. 6.

Metaxas, A., Saunders, M., 2009. Quantifying the "Bio-" Components in Biophysical Models of Larval Transport in Marine Benthic Invertebrates: Advances and Pitfalls. Biol. Bull. 216, 257-272.

Narváez, D.A., Klinck, J.M., Powell, E.N., Hofmann, E.E., Wilkin, J., Haidvogel, D.B., 2012. Circulation and behavior controls on dispersal of eastern oyster (Crassostrea virginica) larvae in Delaware Bay. J. Mar. Res. 70, 411-440.

Orlic, M., Gacic, M., Laviolette, P.E., 1992. The currents and circulation of the Adriatic Sea. Oceanol. Acta 15, 109-124.

Padrón, M., Guizien, K., 2015. Modelling the effect of demographic traits and connectivity on the genetic structuration of marine metapopulations of sedentary benthic invertebrates. ICES J. Mar. Sci. J. Cons. fsv158. doi:10.1093/icesjms/fsv158

Pecarevic, M., Mikus, J., Cetinic, A.B., Dulcic, J., Calic, M., 2013. Introduced marine species in Croatian waters (Eastern Adriatic Sea). Mediterr. Mar. Sci. 14, 224-237. 
Rossi, V., Ser-Giacomi, E., López, C., Hernández-García, E., 2014. Hydrodynamic provinces and oceanic connectivity from a transport network help designing marine reserves. Geophys. Res. Lett. 41, $2883-$ 2891. doi:10.1002/2014GL059540

Rosvall, M., Bergstrom, C.T., 2008. Maps of random walks on complex networks reveal community structure. Proc. Natl. Acad. Sci. 105, 1118-1123. doi:10.1073/pnas.0706851105

Schiavina, M., Marino, I. a. M., Zane, L., Melià, P., 2014. Matching oceanography and genetics at the basin scale. Seascape connectivity of the Mediterranean shore crab in the Adriatic Sea. Mol. Ecol. 23, 5496-5507. doi:10.1111/mec.12956

Schunter, C., Carreras-Carbonell, J., Macpherson, E., Tintoré, J., Vidal-Vijande, E., Pascual, A., Guidetti, P., Pascual, M., 2011. Matching genetics with oceanography: directional gene flow in a Mediterranean fish species. Mol. Ecol. 20, 5167-5181. doi:10.1111/j.1365-294X.2011.05355.x

Shanks, A.L., 2009. Pelagic Larval Duration and Dispersal Distance Revisited. Biol. Bull. 216, 373-385.

Tonani, M., Salon, S., Korres, G., Bolzon, G., Clementi, E., Cossarini, G., Crise, A., Drudi, M., Fratianni, C., Girardi, G., others, 2013. The Mediterranean Monitoring and Forecasting Centre, a component of the MyOcean system, in: EGU General Assembly Conference Abstracts. p. 13628.

Treml, E.A., Halpin, P.N., Urban, D.L., Pratson, L.F., 2007. Modeling population connectivity by ocean currents, a graph-theoretic approach for marine conservation. Landsc. Ecol. 23, 19-36. doi:10.1007/s10980-007-9138-y

Treml, E.A., Roberts, J.J., Chao, Y., Halpin, P.N., Possingham, H.P., Riginos, C., 2012. Reproductive Output and Duration of the Pelagic Larval Stage Determine Seascape-Wide Connectivity of Marine Populations. Integr. Comp. Biol. 52, 525-537. doi:10.1093/icb/ics101

Verri, G., Pinardi, N., Oddo, P., Ciliberti, S., Coppini, G., 2014. The influence of the river inflow on the circulation and dynamics of the Adriatic and Northern Ionian Sea. Presented at the EGU General Assembly Conference Abstracts, p. 16855.

Vilà, M., Basnou, C., Gollasch, S., Josefsson, M., Pergl, J., Scalera, R., 2009. One Hundred of the Most Invasive Alien Species in Europe, in: Handbook of Alien Species in Europe, Invading Nature Springer Series in Invasion Ecology. Springer Netherlands, pp. 265-268.

Villamor, A., Costantini, F., Abbiati, M., 2014. Genetic Structuring across Marine Biogeographic Boundaries in Rocky Shore Invertebrates. PLoS ONE 9. doi:10.1371/journal.pone.0101135

Wilhelmsson, D., Malm, T., 2008. Fouling assemblages on offshore wind power plants and adjacent substrata. Estuar. Coast. Shelf Sci. 79, 459-466. doi:10.1016/j.ecss.2008.04.020

Zavatarelli, M., Raicich, F., Bregant, D., Russo, A., Artegiani, A., 1998. Climatological biogeochemical characteristics of the Adriatic Sea. J. Mar. Syst. 18, 227-263. doi:10.1016/S0924-7963(98)00014-1

Zenetos, a, Gofas, S., Morri, C., Rosso, A., Violanti, D., Garcia Raso, J.E., Cinar, M.E., Almogi-Labin, A., Ates, A.S., Azzurro, E., Ballesteros, E., Bianchi, C.N., Bilecenoglu, M., Gambi, M.C., Giangrande, A., Gravili, C., Hyams-Kaphzan, O., Karachle, P.K., Katsanevakis, S., Lipej, L., Mastrototaro, F., Mineur, F., Pancucci-Papadopoulou, M.A., Ramos Espla, A., Salas, C., San Martin, G., Sfriso, A., Streftaris, N., Verlaque, M., 2012. Alien species in the Mediterranean Sea by 2012. A contribution to the application of European Union's Marine Strategy Framework Directive (MSFD). Part 2. Introduction trends and pathways. Mediterr. Mar. Sci. 13. doi:10.12681/mms.327

Zhang, X., Munroe, D., Haidvogel, D., Powell, E.N., 2016. Atlantic surfclam connectivity within the Middle Atlantic Bight: Mechanisms underlying variation in larval transport and settlement. Estuar. Coast. Shelf Sci. 173, 65-78. doi:10.1016/j.ecss.2016.02.019 


\section{Supplementary file captions}

2 S1. Latitudes and longitudes of the centroids of the grids used in the Adriatic to determine particle source 3 (start) and sink (end) locations. Adriatic was subdivided into a $0.0625^{\circ} \times 0.0625^{\circ}$ grid, with each grid cell 4 approx. $6.7 \mathrm{~km}^{2}$, to match the hydrodynamic model. Total number of grids in the Adriatic (potential sink 5 locations) is 5076. Total number of release grids (source locations) is 383. Highlighted cells indicate release 6 grids.

7 S2. Probability matrix which indicates the probability of particles reaching sink locations for all larval source 8 grids for the PLD4 simulations. Probabilities are calculated from an amalgamation of all years.

9 S3. Probability matrix which indicates the probability of particles reaching sink locations for all larval source 10 grids for the PLD8 simulations. Probabilities are calculated from an amalgamation of all years.

11 S4. Probability matrix which indicates the probability of particles reaching sink locations for all larval source grids for the PLD16 simulations. Probabilities are calculated from an amalgamation of all years.

13 S5. Probability matrix which indicates the probability of particles reaching sink locations for all larval source grids for the PLD20 simulations. Probabilities are calculated from an amalgamation of all years. 